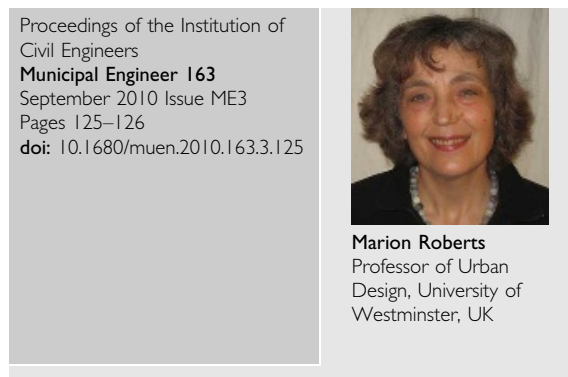

\title{
Editorial: Historic cities as living places
}

M. Roberts PhD, ARB, FHEA

'History', Stephen said, 'is a nightmare from which I am trying to awake'.

The protagonist of Joyce's famous novel Ulysses was no doubt expressing a sentiment that has crossed many a municipal engineer's mind in moments of crisis. These moments of anguish may be brought on by the many and various challenges that face the numerous towns and cities across the globe that contain elements of historic fabric. Indeed, the definition of what is historic fabric is itself subject to contestation and argument. Most recently the UK government has issued new planning guidance (CLG, 2010) that refers to 'heritage assets', which, as one commentator has pointed out, can refer to things that 'actually do not have to be historic at all' (Adams, 2010).

The challenges to historic cities are ever-changing. The expansion of mass travel has stimulated tourism, which has led to an increased appreciation of conservation and heritage, but has also provoked criticisms about a loss of identity and authenticity and an over-emphasis on consumption and gentrification. Contemporary issues, pulling in different directions, exert their own tensions. On the one hand there is a need to cope with the demands of transport, be it public transport or the private car; and on the other, the need to grapple with concerns about climate change.

Over and above all of these, there are people to consider. It is a truism that people make places through their activities and movement and the feelings they invest in specific places or buildings. The architect Aldo Rossi (1982) described buildings that were no longer part of the living architecture of the city as 'pathological', that is, elements that can eventually contribute to the 'death' of a town or city. The common theme that runs through this themed issue is the need to understand, retain and adapt historic towns and cities as living places that have a viable future as well as a past that can be cherished.

This issue of sustainability and its relationship to conservation and preservation is tackled head-on in the first paper, which addresses 'The problem of sustainability and the historic city' (Law, 2010). In this contribution to theory Law provides the reader with a brief review of the evolution of key debates and policy in British conservation and revitalisation. He posits an approach to conservation that values the interpretation of different groups within specific localities.
Further depth to understanding how an economic approach to conservation has brought benefits and disbenefits is provided by the two papers that follow. Human's paper on tourism and place examines the policy relationship between tourism and planning (Human, 2010). In addition to a useful overview of the evolution of UK policy and a critique of its implementation, Human suggests how current difficulties might be overcome through a more integrated, holistic approach. Bristow (2010) reviews and critiques the recent fashion for culture-led regeneration. Focusing on museums and drawing on international examples, Bristow discusses the limitation of the cultural flagship approach and argues for valuing museums for their role in building social capital, a point that resonates with Law's plea for the recognition of the importance of social sustainability.

Globalisation imposes its own inequalities on people and territories, devaluing former industrial areas in the 'north' and fuelling the 'tiger' economies of the 'south'. Two papers in this issue deal with these opposing forces. In a study of plans to revitalise the cathedral city of Durham, Pugalis (2010) explains how a thoughtful masterplan seeks to encourage and support new economic development whilst at the same time recognising how this objective can conflict with heritage values. He applauds the attempt at open democracy in a dialogue between the different actors involved. Meanwhile, in their study of the conservation of Beijing's historic lanes and courtyard homes, Heath and Tang (2010) explain how the dynamism of China's economic engine has threatened the identity of this major global city. Conservation has come from the "bottom up' and it remains to be seen how extensive it can be.

Beijing's historic urban forms support sustainable forms of transport, such as cycling and walking. Regrettably western European urbanism has embraced the internal combustion engine and accommodating vehicles and traffic poses a major challenge for many historic cities. Ramírez Chasco et al. (2010) discuss an inspiring example of how such a challenge can be turned into an opportunity in their home city of Pamplona, Spain. Here a bus garage, parking and commercial space has been carved out beneath a historic monument and its associated green space. The works have even assisted in locating and preserving archaeological remains. A more modest, but none the less valuable example of locally-specific preservation comes from Cornwall. Cocks (2010) discusses how new uses have been found for locally-sourced materials in improvements within former mining settlements that now have World Heritage status. 
The final two papers in this issue bring the discussion full circle, returning to the themes of conservation, sustainability and living places. Lloyd-Jones (2010) reports on a study that explores the potential for retrofitting energy-saving measures in London's Soho, itself a thriving and multi-functional neighbourhood. He details the measures that could be taken and discusses the benefits of using a typological approach for policy guidance. The author notes how the conflicting interests of landlords and commercial tenants hold back advances. Finally, Zhu and Goethert (2010) discuss three different approaches to conservation in historic cities in China, highlighting the competing interests of developers, government and local people. They conclude that there is no single 'best' approach to suit all situations 'as we strive for liveable, economically viable cities'.

The great historian E H Carr wrote in the 1960s of his concern for the paradox that in a world where there was so much 'superficial talk' of change, change was:

no longer thought of as achievement, as opportunity as progress, but as an object of fear (Carr, 1963:155)

Perhaps, like Carr, we should be optimists.

\section{REFERENCES}

Adams R (2010) PPS5 and the three rules of bureaucracies. Planning in London 74: 55.

Bristow P (2010) Using heritage in regeneration: the role of museums. Proceedings of the Institution of Civil Engineers, Municipal Engineer 163(3): 139-144, doi: 10.1680/ muen.2010.163.3.139.

Carr EH (1963) What is History? Pelican, Harmondsworth. CLG (2010) Planning Policy Statement 5: Planning for the Historic Environment. TSO, London. See http://www. communities.gov.uk/publications/planningandbuilding/ pps5 for further details (accessed 09/08/2010).
Cocks A (2010) Preservation of World Heritage mining settlements in Cornwall. Proceedings of the Institution of Civil Engineers, Municipal Engineer 163(3): 169-178, doi: 10.1680/muen.2010.163.3.169.

Heath T and Tang Y (2010) Beijing's hutong and siheyuan: conservation of an urban identity. Proceedings of the Institution of Civil Engineers, Municipal Engineer 163(3): 155-161, doi: 10.1680/muen.2010.163.3.155.

Human B (2010) Tourism and place - towards an alliance of policies. Proceedings of the Institution of Civil Engineers, Municipal Engineer 163(3): 131-138, doi: 10.1680/ muen.2010.163.3.131.

Law A (2010) The problem of sustainability and the historic city. Proceedings of the Institution of Civil Engineers, Municipal Engineer 163(3): 127-130, doi: 10.1680/ muen.2010.163.3.127.

Lloyd-Jones T (2010) Retrofitting sustainability to historic city core areas. Proceedings of the Institution of Civil Engineers, Municipal Engineer 163(3): 179-188, doi: 10.1680/ muen.2010.163.3.179.

Pugalis L (2010) The incremental renaissance of the historic city of Durham. Proceedings of the Institution of Civil Engineers, Municipal Engineer 163(3): 145-153, doi: 10.1680/ muen.2010.163.3.145.

Ramírez Chasco F, Seco Meneses A and Prieto Cobo E (2010) Urban parks as a result of coordinated comprehensive projects. Proceedings of the Institution of Civil Engineers, Municipal Engineer 163(3): 163-168, doi: 10.1680/ muen.2010.163.3.163.

Rossi A (1982) The Architecture of the City. MIT Press, Cambridge, MA.

Zhu L and Goethert R (2010) Different approaches in conservation of historic cities in China. Proceedings of the Institution of Civil Engineers, Municipal Engineer 163(3): 189-196, doi: 10.1680/muen.2010.163.3.189. 